\title{
KAJIAN PERUBAHAN PENGGUNAAN LAHAN MENGGUNAKAN SISTEM INFORMASI GEOGRAFIS (SIG) DAN PENGINDERAAN JAUH DI DISTRIK ORANSBARI, MANOKWARI SELATAN
}

\section{(Study of Land Use Conversion Using Geographical Information System [GIS] and Remote Sensing in Oransbari Sub-District of Manokwari Selatan)}

\author{
Feronika Womsiwor ${ }^{1}$ Francina F. Kesaulija ${ }^{1 凶}$ dan Devi Manuhua ${ }^{1}$ \\ Jurusan Kehutanan, Fakultas Kehutanan Universitas Papua Manokwari, Papua Barat, \\ 98314. Tlp/Fax: +62986211065. \\ ${ }^{\square}$ Penulis Korespondensi: Email: f.kesaulija@gmail.com \\ Diterima: 19 Feb 2019| Disetujui: 10 Mar 2019
}

\begin{abstract}
Abstrak
Tujuan dari penelitian ini adalah mengkaji bentuk-bentuk penggunaan lahan serta mengukur laju perubahan penggunaan lahan pada tahun 2006 sampai tahun 2014 di wilayah Distrik Oransbari Kabupaten Manokwari Selatan. Penelitian ini menggunakan metode penginderaan jauh dengan pendekatan spektral, yaitu klasifikasi penggunaan lahan melalui analisis lebih dari satu saluran citra landsat dengan data yang bersumber dari citra digital landsat 8 tahun perekaman 2014. Hasil penelitian mengidentifikasi luas kawasan sebesar $33.518,69$ ha yang terdiri atas 11 bentuk penggunaan lahan, yaitu hutan lahan kering primer seluas $\pm 18.808,92$ ha $(56,11 \%)$, hutan lahan kering sekunder seluas $\pm 4.525,49$ ha $(13,50 \%)$, hutan mangrove seluas $\pm 362,07$ ha $(1,08 \%)$, pemukiman seluas $\pm 431,98$ ha $(1,29 \%)$, perkebunan seluas $\pm 991,65$ ha $(2,96 \%)$, pertanian lahan kering seluas $\pm 1.174,61$ ha $(3,50 \%)$, savana seluas $\pm 732,93$ ha $(2,19 \%)$, sawah seluas $\pm 514,14$ ha $(1,53 \%)$, semak belukar seluas $\pm 1.570,29$ ha $(4,68 \%)$, tanah terbuka seluas $\pm 49,23$ ha $(0,15 \%)$ dan badan air seluas $\pm 95,67$ ha $(0,29 \%)$. Sebelas penggunaan lahan di Distrik Oransbari juga terbagi dalam tiga fungsi kawasan hutan yaitu cagar alam, hutan lindung dan hutan produksi konversi.
\end{abstract}

Kata kunci: sistem informasi geografis, penginderaan jauh, perubahan lahan, cagar alam, fungsi hutan

\begin{abstract}
This study desires to inquire types of land use and measures land use conversion rate from 2006 to 2014 in Oransbari sub-district of Manokwari Selatan. In dealing with the study, remote sensing through spectral approch is preffered of which lands are classified by way of more than one analysis of landsat imagery channels with data that originated from digital landsat imagery 8 for recording year of 2014. The result has identified the total measured area of 33,518.69 ha which consisted of 11 land use types. These types were primary dryland forest with an approximately of $18,808.92$ ha $(56.11 \%)$, secondary dryland forest with the total area of 4,525.49 ha (13,50\%), mangrove forest was about 362.07 ha (1.08\%), settlement area with roughtly 431.98 ha (1.29\%), plantation area was around $991.65 \mathrm{ha}(2.96 \%)$, agriculture land was roughly 1174.61 ha (3.50\%), savana was approximately $732.93 \mathrm{ha}$ (2.19), paddy land to be reached 514.14 ha (1.53\%), bushes was
\end{abstract}


about 1,570.29 ha (4.68\%), open land was approximately 49.23 ha (0.15\%), and water accupation was roughtly 95.67 ha (0.29\%). The eleven identified land use types in Oransbari sub-district were also divided into three forest functions that are nature preserve area, protected forest, and production forest for conversion.

Keywords: geographical information system, remote sensing, land conversion, nature preserve, forest function

\section{PENDAHULUAN}

Penggunaan lahan merupakan informasi penting dalam kajian sumber daya lahan dan perencanaan wilayah (Feriyawan dan Danoedoro 2012). Pada saat ini informasi penggunaan lahan yang mutakhir telah mampu disediakan oleh penginderaan jauh melalui perekaman satelit. Penginderaan jauh merupakan salah satu teknologi yang dinilai efektif dalam menyelesaikan permasalahanpermasalahan yang ada di perkotaan dengan biaya yang sedikit dan dalam waktu yang relatif singkat (Wibowo dan Suharyadi 2012). Citra satelit (CS) yang cukup banyak digunakan dalam kajian perkotaan umumnya memiliki resolusi spasial menengah. CS tersebut mampu memberikan kenampakan penggunaan lahan pada suatu wilayah maupun terhadap pertumbuhan penduduk dan aktifitasnya. Konsekuensi penggunaan lahan memiliki korelasi positif terhadap perubahan waktu, dimana semakin meningkat jumlah penduduk dan semakin intensifnya aktifitas penduduk di suatu tempat berdampak pada meningkatnya perubahan penutupan lahan (As-Syakur 2011).

Perubahan penggunaan lahan adalah bertambahnya suatu penggunaan lahan dari satu sisi pegunungan ke pegunungan yang lainnya diikuti dengan berkurangnya tipe penggunaan lahan yang lain dari satu waktu ke waktu berikutnya, atau berubahnya fungsi suatu lahan pada kurun waktu yang berbeda (Martin 1993 dalam Wahyunto dkk. 2001). Perubahan penggunaan lahan memiliki dampak potensial besar terhadap lingkungan fisik dan sosial. Selain itu, perubahan penggunaan lahan dapat mempengaruhi sistem ekologi setempat diantaranya pencemaran air, polusi udara, perubahan iklim lokal, berkurangnya keanekaragaman hayati serta terjadinya fluktuasi pelepasan dan penyerapan $\mathrm{CO}_{2}$ (As-Syakur 2011).

Identifikasi perubahan penggunaan lahan pada suatu wilayah memerlukan suatu data spasial multi temporal yang mampu menunjukkan spesifik arah perubahan sesuai waktu. Data-data spasial tersebut dapat bersumber dari hasil interpretasi citra satelit maupun data-data tematik milik instansi-instansi pemerintah yang selanjutnya dapat digunakan untuk kepentingan analisis menggunakan Sistem Informasi Geografis (SIG). Pemanfaatan SIG dan CS merupakan suatu teknologi yang baik dalam mengolah data spasial multi temporal dalam mendeteksi karakteristik perubahan penggunaan lahan suatu wilayah yang berguna untuk pengelolaan sumberdaya alam berkelanjutan, serta dapat dijadikan suatu informasi dalam merencanakan tata ruang di masa yang akan datang. Adanya SIG memudahkan pengolahan data penelitian, karena SIG dapat menangani data bereferensi geografis dengan proses pemasukan, pengelolaan, dan managemen 
data, memanipulasi dan analisis serta keluaran.

Mengingat sumber data sebagian berasal dari data penginderaan jauh baik berasal dari satelit maupun teristerial terdigitasi, maka teknologi SIG erat kaitannya dengan teknologi penginderaan jauh. Penelitian ini menggunakan Citra Landsat 8 yang merupakan jenis produk data penginderaan jauh dalam mendukung penelitian perubahan penggunaan lahan. Citra Landsat TM yang terdiri dari 8 saluran, sehingga dapat memberikan informasi obyek secara detail. SIG dalam penelitian perubahan penggunaan lahan berguna dalam penggabungan (overlay) antara penggunaan lahan pada tahun 2006, 2009, 2012 sampai dengan penggunaan lahan pada tahun 2014 untuk membentuk peta perubahan penggunaan lahan yang berisi informasi tentang laju pertumbuhan penggunaan lahan pada daerah penelitian.

Oransbari memiliki luas kawasan sebesar 33.518, 69 ha dan telah mengalami peningkatan penggunaan lahan. Kenampakan penutupan lahan wilayah ditunjukkan oleh terjadinya pergeseran dari hutan menjadi non-hutan dan hutan dimanfaatkan untuk kegiatan pertanian, permukiman dan lain sebagainya. Kawasan hutan di Distrik Oransbari walaupun jauh dari pusat kota Manokwari namun dapat mengalami perubahan penutupan lahan karena aktivitas masyarakat di sekitar kawasan hutan yang tinggi. Penggunaan lahan yang terjadi dari tahun ke tahun dapat menyebabkan berkurangnya potensi hutan di Distrik Oransbari sebagai sumber keanekaragaman hayati. Hal ini ditunjukkan oleh fungsi kawasan Cagar Alam dan Hutan Lindung di daerah ini sekaligus sebagai sumber pemenuhan kebutuhan bagi masyarakat yang ada di kawasan hutan tersebut.

Distrik Oransbari merupakan salah satu distrik yang terletak di Kabupaten Manokwari Selatan yang telah mengalami pemekaran sesuai dengan Undang-undang Nomor 23 tahun 2012 tentang Pembentukkan Kabupaten Manokwari Selatan di Provinsi Papua Barat. Daerah Oransbari memiliki wilayah cukup luas dengan tingkat pemanfaatan hutan yang cukup tinggi. Hal-hal ini ditunjukkan dengan penggunaan lahan untuk pertanian dan permukiman. Bentuk-bentuk penggunaan lahan yang dominan di daerah ini adalah pembukaan lahan pertanian untuk persawahan dan ladang. Selain itu, perkembangan daerah Manokwari Selatan berdampak terhadap bentuk penggunaan lahan untuk permukiman, perkantoran maupun perekonomian. Selain itu Distrik Oransbari merupakan pusat pertanian di wilayah Manokwari Selatan. Hal tersebut tentunya akan mempengaruhi penggunaan lahan yang dikhawatirkan berpengaruh pada perubahan luasan kawasan hutan yang terdapat di Distrik Oransbari Kabupaten Manokwari Selatan. Penelitian ini bertujuan untuk mengkaji bentukbentuk penggunaan lahan serta mengukur laju perubahan luas penggunaan lahan pada tahun 2006 sampai tahun 2014 di wilayah Distrik Oransbari Kabupaten Manokwari Selatan. Manfaat penelitian ini adalah menjadi informasi dasar dalam perencanaan pembangunan di Distrik Oransbari serta sebagai acuan data penelitian-penelitian selanjutnya.

\section{METODE PENELITIAN}

Metode penelitian yang digunakan dalam penelitian ini adalah metode penginderaan jauh dengan pendekatan 
spektral, yaitu klasifikasi penggunaan lahan melalui analisis lebih dari satu saluran Citra Landsat. Data yang digunakan adalah data citra digital landsat 8 tahun perekaman 2014. Selain itu dilakukan analisis data sekunder peta tematik penggunaan lahan tahun 2006, 2009 dan 2012. Secara lebih rinci metode yang digunakan dalam penelitian ini akan diuraikan sebagai berikut :

\section{Waktu dan Tempat}

Penelitian ini dilaksanakan \pm 1 bulan dari bulan September sampai bulan Oktober tahun 2014 pada Distrik Oransbari Kabupaten Manokwari. Lokasi ini dipilih karena merupakan salah satu Pusat Pertanian Daerah Manokwari Selatan.

\section{Bahan dan Alat}

Bahan penelitian yang akan digunakan, sebagai berikut.

1. Peta Rupa Bumi Indonesia (RBI) skala 1: 50.000 tahun 2009 lembar 301451/3014-52

2. Peta Penggunaan Lahan tahun 2006, 2009 dan 2012 skala 1: 250.000

3. Citra Landsat 8 (Multispektral) resolusi $30 \mathrm{~m}$ perekaman tahun 2014

4. Peta Batas Administrasi Kabupaten Manokwari Selatan skala 1:50.000

5. Peta Fungsi Kawasan Hutan Skala 1 : 250.000 (BPKH Wilayah XVII, Manokwari)

Alat yang akan digunakan dalam penelitian meliputi:

1. Seperangkat keras berupa personal computer dengan Prosesor Intel ${ }^{\circledR}$ Celeron ${ }^{\circledR}$ CPU 1007U @ 1,50GHz, RAM 2.00 Gb (1.79 Gb usable) HDD $750 \mathrm{~Gb}$, VGA Intel Inside dan system type 32 bit Operating System.
2. Perangkat lunak computer, Arc GIS 10.2.2 yang memiliki fungsi untuk mengolah data, menyimpan, menganalisis dan menampilkan kembali informasi geografis yang telah dibuat.

3. Perangkat Lunak Envi/ Ermapper

4. Microsoft EXCEL 2010 untuk melakukan pengolahan dan analisis data

5. GPS (Global Positioning System) Garmin digunakan untuk menunjukkan koordinat sampel di lapangan berdasarkan letak sampel yang sebelumnya telah di plotkan dalam peta. Tipe GPS yang dipakai adalah tipe GPS map 78s.

6. Mapsource digunakan untuk menginput data dari perangkat lunak ke GPS yang sudah di plotkan dan sebaliknya dari GPS ke perangkat lunak.

\section{Pengumpulan Data}

Dalam penelitian ini digunakan data primer yang diperoleh dari peta tematik penggunaan lahan, Citra Landsat dan hasil kerja lapangan. Sedangkan data sekunder yang digunakan dalam penelitian ini adalah data Penggunaan Lahan. Data sekunder yang dipergunakan dalam penelitian ini untuk membantu analisis peneliti dalam mengkaji perubahan penggunaan lahan.

\section{Tahap-Tahap Penelitian}

Tahap penelitian yang dilakukan merupakan bagian yang tidak terpisahkan satu dengan yang lain. Tahap-tahap penelitian dibagi menjadi tiga tahap, yaitu tahap persiapan, tahap pelaksanaan dan analisis data serta tahap penyelesaian. Keseluruhan tahap tersebut harus 
dilakukan secara berurutan, sehingga tercapai tujuan penelitian.

\section{Tahap Persiapan}

Kegiatan yang termasuk dalam tahap persiapan ini adalah :

1. Studi pustaka

Studi ini untuk mempelajari pustaka yang berkaitan dengan penggunaan lahan dan data yang akan digunakan, baik data primer maupun data sekunder.

2. Persiapan bahan dan alat

Pada tahap ini dilakukan pengumpulan data, yaitu :

a. Peta dasar yang diperoleh dari instansi kebumian, yaitu Peta Rupa Bumi Indonesia (RBI) dari Bakosurtanal. Peta Rupa Bumi yang digunakan sebagai peta dasar untuk digitasi adalah lembar asli (301451/53) dan dalam format digital, hal ini disebabkan kenampakan simbol dari objek tersebut mudah dibedakan saat didigitasi dan tidak mengalami perubahan skala.

b. Citra Landsat

Citra Landsat yang digunakan merupakan hasil klasifikasi multispektral yang memenuhi kaidah penentuan kelas penggunaan untuk kebutuhan analisis penggunaan lahan. Citra Landsat merupakan hasil perekaman tahun 2014 yang mencakup lembar Manokwari Selatan dan sekitarnya.

c. Data penggunaan lahan

Data bentuk-bentuk penggunaan lahan yang secara umum telah diperoleh melalui studi pustaka dan hasil interpretasi penggunaan lahan.

Tahap Pelaksanaan dan Analisis

1. Prapemrosesan data digital landsat

a. Koreksi geometrik
Perolehan data penginderaan jauh dengan wahana satelit relatif terbebas dari kesalahan panoramik dan pergeseran relief. Meskipun demikian data landsat masih mengandung berbagai distorsi geometrik yang harus dikoreksi. Distorsi geometrik pada data landsat disebabkan oleh beberapa faktor seperti tinggi satelit, ketegakan satelit, dan kecepatannya. Secara umum distorsi geometrik pada sistem penginderaan jauh dengan wahana satelit dibagi menjadi dua yaitu distorsi yang dapat diperkirakan (sistematik) dan distorsi tidak dapat diperkirakan (acak) (Lillesand dan Kieffer 1990 dalam Lainatussifa 2005).

Koreksi geometrik dilakukan mempunyai tiga tujuan, yaiu (1) melakukan rektifikasi (pembetulan) citra agar koordinat citra sesuai dengan koordinat geografis; (2) registrasi (mencocokkan) posisi citra dengan citra lain atau mentransformasikan sistem koordinat citra multispektral atau citra multi temporal; (3) registrasi citra ke peta atau transformasi sistem koordinat citra ke peta, yang menghasilkan citra dengan sistem proyeksi tertentu. Oleh karena itu koreksi geometrik dilakukan dengan proses transformasi, yang ditetapkan melalui hubungan sistem koordinat citra dan sistem koordinat geografi. Transformasi yang dipergunakan adalah transformasi orde 1 karena daerah yang dikoreksi permukaannya datar sehingga sekurang-kurangnya harus memiliki 6 titik kontrol, semakin banyak 
maka semakin baik hasilnya. Sebagai hasilnya tiap citra yang telah dikoreksi dengan sistem proyeksi UTM memiliki metrik sesuai dengan peta dasar.

b. Cropping

Cropping dilakukan untuk memotong citra sesuai batas daerah penelitian yaitu Distrik Oransbari Kabupaten Manokwari Selatan. Hal ini dikarenakan hanya memonitoring perubahan penggunaan lahan yang ada pada Distrik Oransbari Kabupaten Manokwari Selatan. Pemotongan citra dilakukan menggunakan perangkat lunak Arcgis 10.2.2

c. Interpretasi

Interpretasi penggunaan lahan dalam Citra Landsat untuk memonitoring perubahan penggunaan lahan dilakukan berdasarkan unsur-unsur interpretasi. Unsur-unsur interpretasi menurut Purwadhi dan Sanjoto 2008, diantaranya :

- Rona/warna

Gradiasi rona merupakan salah satu unsur interpretasi yang utama dalam interpretasi Citra Landsat.

- Bentuk

Bentuk adalah variabel kualitatif yang menguraikan konfigurasi atau kerangka suatu objek, misalnya persegi, membulat, memanjang, dan bentuk lainnya. Bentuk juga menyangkut susunan atau struktur yang lebih rinci.

- Ukuran

Ukuran merupakan aribut objek yang berupa jarak, luas, tinggi, lereng dan volume.
- Tekstur

Tekstur adalah frekuensi perubahan rona di dalam citra dan erat hubungannya dengan skala yang digunakan serta ukuran dan susunan objek itu sendiri. Tekstur dapat mencerminkan topografi suatu daerah yang timbul dari adanya efek bayangan.

- Pola

Pola merupakan susunan keruangan suatu objek. Pola merupakan pengulangan dari bentuk umum atau hubungan tertentu, yang merupakan karakteristik dari objek bentukan manusia dan objek alamiah.

- Bayangan

Bayangan merupakan objek yang tampak samar-samar atau tidak tampak sama skali (hitam) sesuai dengan bentuk objeknya, seperti bayangan awan, bayangan gedung, bayangan bukit.

- Letak/site

Site adalah lokasi objek dalam hubungannya dengan lingkunga sekitarnya (Sutanto 1987).

- Asosiasi

Asosiasi merupakan unsur antar objek yang keterkaitan atau antara objek yang satu dengan yang lain, sehingga berdasarkan asosiasi tersebut dapat membentuk suatu fungsi objek tertentu. Misalnya pelabuhan merupakan asosiasi dari kenampakan laut, dermaga, kapal, bangunan gudang, tempat tunggu penumpang dan lapangan tempat parkir kontiner. 
d. Survei lapangan

Kerja lapangan merupakan kegiatan yang dilakukan untuk mencocokkan perubahan penggunaan lahan hasil interpretasi citra dengan keadaan di lapangan. Lokasi penelitian ditentukan secara purposive sampling, yaitu berdasarkan pertimbangan tertentu. Adapun dasar pertimbangannya adalah pada daerah penelitian terjadi perubahan penggunaan lahan.

Uji lapangan dilaksanakan dengan menggunakan titik sampel dan penentuan titik sampel bertujuan untuk menyederhanakan kegiatan lapangan, sehingga tersusun secara sistematis. Hasil uji lapangan dan interpretasi citra menjadi dasar dalam perhitungan uji ketelitian interpretasi.

e. Overlay

Overlay merupakan sistem untuk menumpangsusunkan beberapa peta sehingga akan didapatkan peta informasi yang baru. Syarat overlay adalah daerah atau lokasinya harus sama, diikuti dengan suatu sistem koordinat, terdiri dari beberapa variabel, dan kriteria khusus yang akan menampilkan data turunan. Prosesnya dilakukan dengan cara intersection, yaitu proses overlay antara dua data grafis.

\section{Analisis data}

Dalam analisis data, hasil pengolahan data serta informasi di lapangan guna mendapatkan peta perubahan penggunaan lahan 2006 dan 2014 yang terbaru. Analisis utama yang dipakai sebagai dasar adalah hasil interpretasi peta tematik penggunaan lahan tahun 2006, pengecekan lapangan serta dari data sekunder dan informasi tentang masalah yang terkait. Interpretasi penggunaan lahan daerah penelitian ini berdasarkan klasifikasi Badan Standar Nasional (BSN) 2010, yang disesuaikan dengan daerah penelitian.

\section{HASIL DAN PEMBAHASAN}

Penelitian perubahan penggunaan lahan di Distrik Oransbari pada tahun 2006 sampai 2014 menggunakan data spasial tematik dan analisis citra satelit. Data spasial tematik yang digunakan untuk mengukur laju perubahan penggunaan lahan adalah peta penggunaan lahan tahun 2006, 2009 dan 2012. Peta tematik ini merupakan hasil interpretasi dan analisis Badan Pemantapan Kawasan Hutan (BPKH) Manokwari. Selain itu, peta penutupan lahan yang dihasilkan adalah data sekunder peta penutupan lahan tahun 2014 yang diperoleh dari interpretasi data digital citra landsat 8 tahun 2014. Analisis citra satelit menggunakan citra satelit Landsat 8 (Citra Multispektral Resolusi 30 meter) yang telah melalui tahapan koreksi radiometrik dan geometrik. Interpretasi citra landsat 8 dilakukan melalui tahapan klasifikasi multispecktral untuk mengenali tipe penutupan lahan. Selain itu, pengenalan karakteristik bentuk penggunaan lahan juga dilakukan melalui pendekatan prinsip-prinsip interpretasi. Penggunaan citra landsat 8 mampu memberikan kenampakan bentuk penggunaan lahan yang cukup baik pada wilayah penelitian Distrik Oransbari Kabupaten Manokwari Selatan.

Wilayah Distrik Oransbari terdiri atas 11 bentuk penggunaan lahan, yaitu hutan lahan kering primer, hutan lahan kering sekunder, hutan mangrove, pemukiman, 
perkebunan, pertanian lahan kering, savana, sawah, semak belukar, tanah terbuka dan badan air.

Dalam penelitian ini dihasilkan peta penutupan lahan dalam empat tahun yang berbeda karena sifat dari penelitian ini adalah multitemporal yaitu menggunakan data dalam referensi waktu yang berbeda. Peta penutupan lahan yang diperoleh ini merupakan hasil dari pengolahan citra digital landsat 8 dengan berbagai tahap pengolahan citra yang didukung dengan beberapa data sekunder berupa batas administrasi, fungsi kawasan hutan dan peta topografi daerah penelitian.

\section{Bentuk-Bentuk Penggunan Lahan di Distrik Oransbari}

Bentuk-bentuk penggunaan lahan yang terjadi di Distrik Oransbari diuraikan sebagai berikut :

\section{a. Hutan Lahan Kering Primer}

Hutan lahan kering primer adalah hutan yang terbentuk secara alami dan telah mencapai kondisi klimaks. Hutan lahan kering primer lebih banyak berada pada wilayah Cagar Alam jika di bandingkan dengan hutan lindung dan hutan produksi konversi. Luas hutan lahan kering primer berdasarkan hasil analisis citra landsat delapan \pm 18808.92 ha $(56,11 \%)$. Hasil pengamatan lapangan berdasarkan penutupan lahan pada areal hutan lahan kering primer ditemukan jenis-jenis tanaman antara lain Merbau (Intsia bijuga), Matoa (Pometia sp.), Palem, Sagu (Metroxylon sp.), Bambu (Bambosa sp.) dan Beringin (Ficus sp.).

\section{b. Hutan Lahan Kering Sekunder}

Hutan lahan kering sekunder adalah hutan primer yang ditebang untuk memenuhi kebutuhan kayu oleh manusia atau dibuka untuk ladang atau terbuka karena banjir atau bencana alam lain, kemudian secara alami terbentuk hutan baru yang belum mencapai klimaks seperti hutan semula. Kenampakan berhutan bekas tebas bakar yang ditinggalkan, bekas kebakaran atau yang tumbuh kembali dari bekas tanah terdegradasi juga dimasukkan dalam kelas ini. hutan lahan kering sekunder pada tahun $2014 \pm 4525.49$ ha $(13,50 \%)$. Hutan lahan kering sekunder di daerah penelitian terdapat jenis tumbuhan Bintangur (Callophyllum sp.), Dahu (Dracontomelon edule), Marsawa (Anisoptera spp.), Matoa (Pometia pinnata), Medang (Litsea spp.), Nyatoh (Palaguium spp.), Pala (Myristica spp.), Pulai (Alstonia scholaris), Resak (Vatica spp.) dan Salam (Eugenia polyantha).

Hutan lahan kering sekunder adalah hutan yang telah mengalami gangguan eksplotasi oleh manusia, biasanya ditandai dengan adanya jaringan jalan ataupun jaringan sistem eksploitasi. Pada peta penutupan lahan di daerah penelitian menunjukkan bentuk penggunaan ini telah dikonversi menjadi sawah, perkebunan, pemukiman, semak belukar dan savana.

\section{c. Hutan Mangrove}

Hutan mangrove adalah jenis hutan yang tumbuh di antara batas permukaan air laut berada di antara lingkungan pantai dan daratan (Zain 1998). Hutan mangrove pada daerah penelitian umummya berada pada Kampung Oransbari. Luas hutan mangrove tahun 2014 berdasarkan hasil analisis citra landsat delapan \pm 362.07 ha $(1,08 \%)$. Vegetasi mangrove yang ditemukan antara lain Avicennia alba, Bruguiera gymnorrhiza, Bruguiera sexangula, Ceriops decandra, Heritiera littoralis, Lumnitzera racemosa, Osbornia octodonta, Rhizophora stylossa, 
Rhizophora mucronata, Rhizophora apiculata, Soneratia alba, Soneratia caseolaris, Xylocarpus mekongensis, dan Xylocarpus sp.. Selain jenis-jenis mangrove, pada daerah peralihan dijumpai juga jenis vegetasi hutan pantai seperti Cocos nucifera, Macaranga mappa, Ficus benjamina, Premna corymbosa, Hibiscus sp., Pandanus sp., dan paku-pakuan (Talane 2014).

\section{d. Pemukiman}

Pemukiman merupakan lahan yang diatasnya terdapat bangunan berupa rumah tempat tinggal beserta pekarangannya dan bangunan lainnya. Objek ini berasosiasi dengan objek jalan pada umumnya pola ini cenderung mengelompok pada daerah tertentu seperti di sepanjang jalan atau perumahan. Beberapa lokasi pemukiman juga diidentifikasi dengan pola yang menyebar seperti di daerah lereng perbukitan. Peta penutupan lahan untuk bentuk penggunaan lahan permukiman menunjukkan perubahan yang cukup besar selama tahun 2006 sampai 2014 yaitu \pm 235.02 ha $(21,37 \%)$. Perubahan ini disebabkan karena Oransbari menjadi pusat perekonomian dan pemerintahan untuk Kabupaten Manokwari Selatan serta sejalan dengan perkembangan wilayah kota dan semakin bertambahnya jumlah penduduk maka luas lahan untuk pemukiman akan semakin meningkat.

\section{e. Perkebunan}

Perkebunan pada daerah penelitian merupakan bentuk penggunaan lahan yang dimanfaatkan untuk kegiatan pertanian jangka panjang. Jenis tanaman yang ditanam sebagai komoditi unggulan adalah tanaman coklat (kakao). Tanaman kakao ini merupakan suatu program peningkatan kesejahteraan masyarakat dalam bentuk kelompok tani kakao di Distrik Oransbari melalui Dinas Pertanian dan Perkebunan Kabupaten Manokwari. Pada peta penutupan lahan tahun 2006 sampai 2014 mengalami perubahan, dimana bentuk penggunaan lahan perkebunan meningkat menjadi \pm 991.65 ha $(2,96 \%)$ yang sebagian daerahnya telah dikonversi menjadi bentuk penggunaan lahan pemukiman.

\section{f. Pertanian Lahan Kering}

Pertanian lahan kering yang terdapat di Distrik Oransbari ada tiga jenis yaitu kebun campur, tegalan dan pekarangan. Kebun campur sebagai daerah yang agak jauh dari permukiman yang berkelompok dan berasosiasi dekat dengan tegalan. Tegalan atau ladang merupakan bentuk penggunaan lahan yang pada umumnya ditanamai jenis tanaman palawija, sedangkan pekarangan adalah pemanfaatan lahan di areal permukiman untuk usaha pertanian. Berdasarkan hasil analisis citra landsat delapan tahun 2014 pertanian lahan kering mengalami penurunan luasan $\pm 231,81$ ha. Jenis tanaman yang tumbuh pada areal ini adalah mangga, kelapa, kedondong, pepaya pisang, pinang, matoa, rambutan, sirsak, jambu, coklat, sukun, langsat, nangka, jagung, kedelai dan beberapa jenis sayuran. Berdasarkan hasil analisis peta tematik tahun 2006 sampai 2012 dan interpretasi citra 2014 penggunaan lahan pertanian lahan kering telah mengalami perubahan. Perubahan pada pertanian lahan kering ini terjadi karena terjadi perubahan bentuk penggunaan lahan yang telah dikonversi menjadi penggunaan lahan untuk permukiman.

\section{g. Savana}

Savana merupakan lahan kering atau daratan yang telah ditumbuhi oleh 
vegetasi alami homogen yang tingkat kerapatannya jarang hingga rapat. Kawasan tersebut didominasi vegetasi rendah (alami). Savana di daerah penelitian memiliki vegetasi alami yang homogen dengan tingkat kerapatan jarang sampai rapat. Savana dalam tahun 2006 sampai 2014 menunjukkan telah terjadi penurunan luasan $\pm 59,59$ ha dengan ratarata laju perubahan per tahun sekitar 5,42 ha yang dikonversi menjadi permukiman.

\section{h. Sawah}

Penelitian ini mendefiniskan sawah irigasi sebagai penggunaan lahan sawah yang diperuntukan untuk kegiatan bercocok tanam padi dengan sistem pengairan irigasi. Peta penutupan lahan untuk bentuk penggunaan lahan sawah menunjukkan perubahan yang cukup besar selama tahun 2006 sampai 2014 yaitu $\pm 141,22$ ha dengan rata-rata laju perubahan 12,84 ha/tahun yang sebelumnya adalah daerah savana, semak belukar dan pertanian lahan kering. Perubahan ini disebabkan karena wilayah Oransbari menjadi pusat pertanian berupa sawah di wilayah Kabupaten Manokwari Selatan. Penambahan luas lahan untuk sawah ini juga didukung oleh ketersediaan dataran alluvial yang cukup luas serta kebutuhan air yang memadai untuk mengairi sawah di daerah tersebut.

\section{i. Semak Belukar}

Semak belukar merupakan kawasan lahan kering yang telah ditumbuhi berbagai vegetasi alami heterogen dan homogen yang tingkat kerapatannya jarang hingga rapat. Kawasan tersebut didominasi vegetasi rendah (alami). Semak belukar di Indonesia biasanya kawasan bekas hutan dan biasanya tidak menampakkan lagi bekas atau bercak tebangan. Hasil pengamatan di daerah penelitian menunjukkan bahwa semak belukar banyak dijumpai didaerah Kampung Margomulyo, Watariri dan Muari. Semak belukar di daerah penelitian memiliki vegetasi alami yang heterogen dengan tingkat kerapatan jarang sampai rapat serta dijumpai jenis beberapa jenis liana. Semak belukar dalam tahun 2006 sampai 2014 telah menunjukkan terjadinya perubahan luasan yang cukup besar $\pm 11,62$ ha dengan rata-rata laju perubahan 1,06 ha/tahun. Berkurangnya bentuk penggunaan lahan semak belukar yang sebagian besar telah dikonversi menjadi penggunaan lahan untuk sawah, selain itu sebagian penggunaan lahan untuk hutan lahan kering sekunder pada cagar alam telah dikonversi menjadi semak belukar, dan semak belukar yang berada pada hutan produksi konversi juga telah mengalami penurunan akibat terkonversi menjadi penggunaan lahan untuk sawah.

\section{j. Tanah Terbuka}

Tanah terbuka merupakan daerah tanpa vegetasi (singkapan batuan puncak gunung, puncak bersalju, kawah vulkan, gosong pasir, pasir pantai, endapan sungai), maupun lahan terbuka bekas kebakaran. Tanah terbuka berada pada fungsi hutan produksi konversi. Lahan terbuka dalam kerangka rotasi tanam sawah/tambak tetap dikelaskan sawah/tambak. Peta penutupan lahan menunjukkan tanah terbuka selama tahun 2006 sampai 2014 mengalami perubahan dengan adanya penambahan luasan sekitar $\pm 9,84$ ha. Daerah ini masih belum digunakan untuk kepentingan pertanian oleh masyarakat setempat maupun menjadi savana. 


\section{k. Badan Air}

Badan air merupakan bentuk penggunaan lahan yang didominasi oleh air. Bentuk penggunaan lahan badan air didaerah penelitian sebagian besar didominasi oleh sungai besar maupun sungai kecil. Sungai yang terdapat didaerah penelitian antara lain sungai Masabui, sungai Wedoni, sungai Wandoki, sungai Watariri, sungai Warbiadi, sungai Maebuki, sungai Warmori, sungai Warkwandi, sungai Misbas, sungai Wariki, dan sungai Warmapi. Peta penutupan lahan menunjukkan badan air selama tahun 2006 sampai 2014 mengalami perubahan $\pm 2,96$ ha. Penggunaan lahan ini hanya digunakan untuk kepentingan pertanian terutama sawah oleh masyarakat setempat dan kebutuhan air bersih.

\section{Perubahan Penggunaan Lahan Tahun 2006 - 2014}

Peta perubahan penggunaan lahan dari tahun 2006, 2009, 2012 hingga 2014 didapatkan dengan mengoverlaykan antara peta penggunaan lahan 2006 dan peta penggunaan lahan 2014. Peta perubahan penggunaan lahan ini merupakan peta yang menunjukkan adanya perubahan luas bentuk penggunaan lahan di wilayah Oransbari dari tahun 2006 sampai tahun 2014. Proses overlay akan melibatkan gabungan data atribut antara kedua peta, sehingga dari data tersebut dapat terlihat perubahan yang terjadi di beberapa wilayah. Kelas penggunaan lahan berdasarkan hasil interpretasi peta tematik dan analisis visual citra Landsat delapan disajikan pada tabel 1 .

Tabel 1. Luas penggunaan lahan di Distrik Oransbari

\begin{tabular}{|c|c|c|c|c|c|c|c|c|c|}
\hline \multirow{3}{*}{ No. } & \multirow{3}{*}{$\begin{array}{c}\text { Bentuk } \\
\text { Penggunaan } \\
\text { Lahan }\end{array}$} & \multicolumn{8}{|c|}{$\begin{array}{l}\text { Luas Penggunaan Lahan Tahun 2006-2014 } \\
\end{array}$} \\
\hline & & \multicolumn{2}{|c|}{2006} & \multicolumn{2}{|c|}{2009} & \multicolumn{2}{|c|}{2012} & \multicolumn{2}{|c|}{2014} \\
\hline & & $\begin{array}{l}\text { Luas } \\
\text { (Ha) }\end{array}$ & $(\%)$ & $\begin{array}{l}\text { Luas } \\
\text { (Ha) }\end{array}$ & $(\%)$ & $\begin{array}{l}\text { Luas } \\
(\mathrm{Ha})\end{array}$ & $(\%)$ & $\begin{array}{l}\text { Luas } \\
(\mathrm{Ha})\end{array}$ & $(\%)$ \\
\hline 1. & $\begin{array}{l}\text { Hutan Lahan } \\
\text { Kering Primer }\end{array}$ & 18277.91 & 54.53 & 22573.48 & 67.35 & 22524.87 & 67.20 & 18808.92 & 56.11 \\
\hline 2. & Semak / Belukar & 1581.91 & 4.72 & 1666.59 & 4.97 & 1768.34 & 5.28 & 1570.29 & 4.68 \\
\hline 3. & $\begin{array}{l}\text { Hutan Lahan } \\
\text { Kering Sekund }\end{array}$ & 6244.49 & 18.63 & 5007.29 & 14.94 & 5011.61 & 14.95 & 4525.49 & 13.50 \\
\hline 4. & $\begin{array}{l}\text { Pertanian Lahan } \\
\text { Kering }\end{array}$ & 1406.42 & 4.20 & 1407.04 & 4.20 & 1254.46 & 3.74 & 1174.61 & 3.50 \\
\hline 5. & Awan & 3141.02 & 9.37 & 0.00 & 0.00 & 0.00 & 0.00 & 4261.64 & 12.71 \\
\hline 6. & Savana & 792.52 & 2.36 & 792.49 & 2.36 & 735.59 & 2.19 & 732.93 & 2.19 \\
\hline 7. & Badan Air & 92.71 & 0.28 & 89.92 & 0.27 & 92.71 & 0.28 & 95.67 & 0.29 \\
\hline 8. & Perkebunan & 961.01 & 2.87 & 961.01 & 2.87 & 961.01 & 2.87 & 991.65 & 2.96 \\
\hline 9. & Pemukiman & 196.96 & 0.59 & 196.92 & 0.59 & 363.20 & 1.08 & 431.98 & 1.29 \\
\hline 10. & Tanah Terbuka & 39.39 & 0.12 & 39.39 & 0.12 & 46.42 & 0.14 & 49.23 & 0.15 \\
\hline 11. & Sawah & 372.92 & 1.11 & 373.09 & 1.11 & 349.03 & 1.04 & 514.14 & 1.53 \\
\hline 12 & Hutan Mangrove & 411.42 & 1.23 & 411.43 & 1.23 & 411.44 & 1.23 & 362.07 & 1.08 \\
\hline & Jumlah & 33518.68 & 100 & 33518.64 & 100 & 33518.69 & 100 & 33518.61 & 100.00 \\
\hline
\end{tabular}

Sumber : analisis peta tematik penggunaan lahan dan interpretasi citra, 2014 
Tabel 1 menunjukkan bahwa sejak tahun 2006 hingga tahun 2014 wilayah Distrik Oransbari mengalami perubahan luas penggunaan lahan. Tahun acuan untuk menghitung perubahan luas adalah tahun yang paling awal yaitu tahun 2006 . Hasil analisis dengan mempergunakan data SIG dan penginderaan jauh pada tabel 1 menunjukkan bahwa luas perubahan penggunaan lahan selama 8 tahun ini bervariasi. Berdasarkan hasil overlay dan analisis citra landsat 8 diketahui bahwa penggunaan lahan terluas dari tahun 2006 sampai 2014 adalah hutan lahan kering primer sedangkan penggunaan lahan dengan

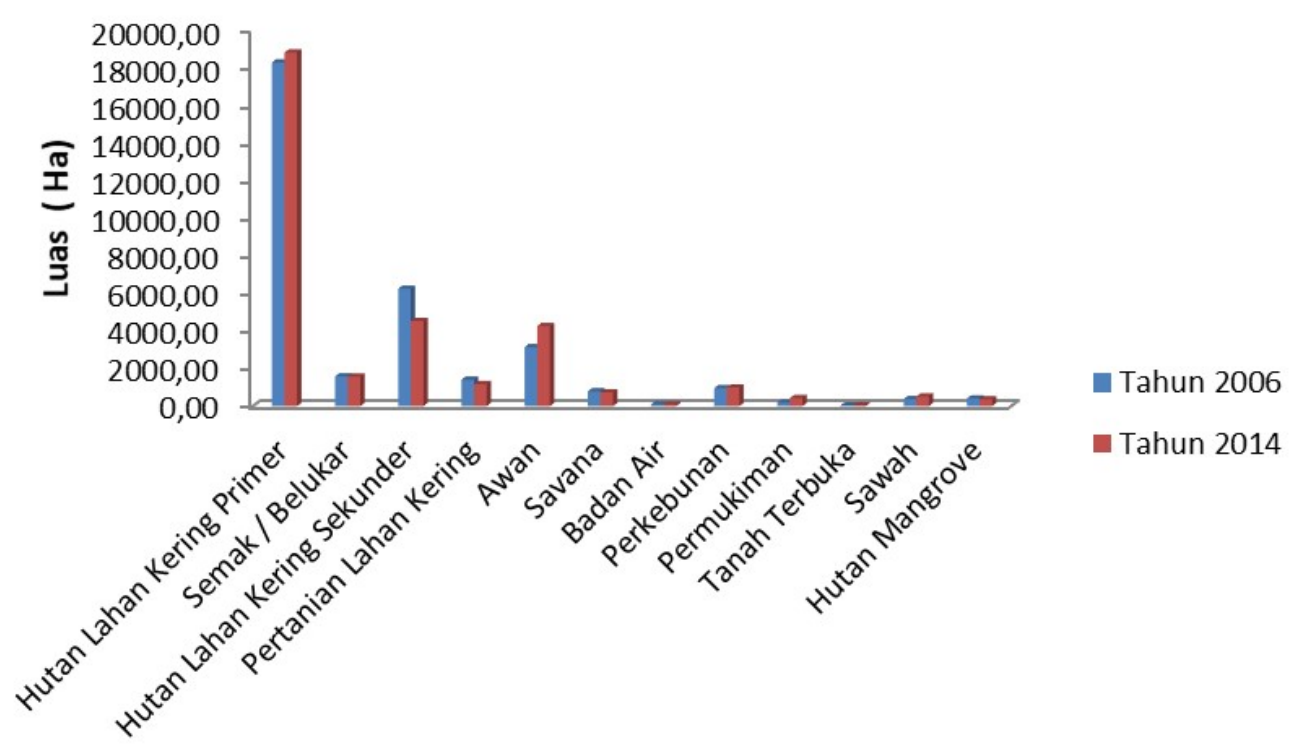

Bentuk Penggunaan Lahan

Gambar 1. Perubahan penggunaan lahan di Distrik Oransbari tahun 2006-2014

Perubahan akan berjalan dengan cepat jika didukung oleh faktor positif yang mempengaruhinya, sebaliknya perubahan akan berjalan lambat jika tidak didukung oleh faktor pendukungnya (Sinaga 2004). Perubahan penggunaan lahan permukiman disebabkan oleh manusia luasaan terkecil adalah tanah terbuka. Bentuk penggunaan lahan hutan lahan kering primer pada tahun 2006 sebesar $18.277,91$ ha $(54,53 \%)$, tahun 2009 sebesar $22.573,48$ ha $(67,35 \%)$, tahun 2012 sebesar $22.524,87$ ha $(67,20 \%)$, dan tahun 2014 sebesar $18.808,92$ ha $(56,11 \%)$. Sedangkan penggunaan lahan tanah terbuka pada tahun 2006 sebesar 39,39 ha $(0,12 \%)$, tahun 2009 sebesar 39,39 ha $(0,12 \%)$, tahun 2012 sebesar 46,42 ha $(0,14 \%)$, dan tahun 2014 sebesar sebesar 49,23 ha $(0,15 \%)$. Perubahan penggunaan lahan tahun 2006 sampai 2014 dapat dilihat pada Gambar 1. 
Tabel 2. Penggunaan lahan tahun 2014 dalam fungsi kawasan hutan di Distrik Oransbari

\begin{tabular}{|c|c|c|c|c|c|c|c|c|c|c|c|c|}
\hline \multirow{3}{*}{ No. } & \multirow{3}{*}{ Bentuk Penggunaan Lahan } & \multicolumn{10}{|c|}{ Penggunaan Lahan dalam Fungsi Kawasan } & \multirow{3}{*}{ Total } \\
\hline & & \multicolumn{2}{|c|}{$\mathrm{CA}$} & \multicolumn{2}{|c|}{ HL } & \multicolumn{2}{|c|}{ HPK } & \multicolumn{2}{|c|}{ APL } & \multicolumn{2}{|c|}{ BA } & \\
\hline & & Luas (Ha) & $\%$ & $\begin{array}{l}\text { Luas } \\
\text { (Ha) }\end{array}$ & $\%$ & $\begin{array}{l}\text { Luas } \\
(\mathrm{Ha})\end{array}$ & $\%$ & $\begin{array}{c}\text { Luas } \\
\text { (Ha) }\end{array}$ & $\%$ & $\begin{array}{l}\text { Luas } \\
\text { (Ha) }\end{array}$ & $\%$ & \\
\hline 1. & Hutan Lahan Kering Primer & 17894.47 & 76.52 & 352.06 & 27.74 & 562.38 & 6.42 & 0.00 & 0.00 & 0.00 & 0.00 & 18808.92 \\
\hline 2. & Semak / Belukar & 96.52 & 0.41 & 428.89 & 33.56 & 1044.87 & 11.92 & 0.00 & 0.00 & 0.00 & 0.00 & 1570.28 \\
\hline 3. & Hutan Lahan Kering Sekunder & 1358.44 & 5.81 & 319.49 & 25.00 & 2847.56 & 32.38 & 0.00 & 0.00 & 0.00 & 0.00 & 4525.49 \\
\hline 4. & Pertanian Lahan Kering & 86.88 & 0.37 & 165.74 & 10.21 & 923.20 & 10.54 & 0.00 & 0.00 & 0.00 & 0.00 & 1174.61 \\
\hline 5. & Savana & 2.65 & 0.01 & 0.00 & 0.00 & 730.28 & 8.34 & 0.00 & 0.00 & 0.00 & 0.00 & 732.93 \\
\hline 6. & Badan Air & 0.00 & 0.00 & 2.63 & 0.00 & 2.37 & 0.03 & 0.77 & 89.90 & 89.90 & 100.00 & 95.67 \\
\hline 7. & Perkebunan & 5.96 & 0.03 & 1.80 & 0.12 & 983.89 & 11.23 & 0.00 & 0.00 & 0.00 & 0.00 & 991.65 \\
\hline 8. & Pemukiman & 1.01 & 0.00 & 3.75 & 7.76 & 427.22 & 4.88 & 0.00 & 0.00 & 0.00 & 0.00 & 431.98 \\
\hline 9. & Tanah Terbuka & 0.00 & 0.00 & 0.00 & 0.00 & 49.23 & 0.56 & 0.00 & 0.00 & 0.00 & 0.00 & 49.23 \\
\hline 10. & Sawah & 0.00 & 0.00 & 0.00 & 0.00 & 514.14 & 6.41 & 0.00 & 0.00 & 0.00 & 0.00 & 514.47 \\
\hline 11. & Hutan Mangrove & 0.00 & 0.00 & 0.52 & 0.04 & 361.55 & 4.13 & 0.00 & 0.00 & 0.00 & 0.00 & 362.07 \\
\hline \multirow[t]{2}{*}{12.} & Awan & 3940.63 & 16.85 & 3.00 & 0.23 & 318.01 & 3.63 & 0.00 & 0.00 & 0.00 & 0.00 & 4261.64 \\
\hline & Total & 23387.57 & 100.00 & 1282.68 & 100.00 & 8757.69 & 100.00 & 0.77 & 100.00 & 89.90 & 100.00 & 33518.61 \\
\hline
\end{tabular}

Sumber : analisis peta tematik penggunaan lahan dan interpretasi citra, 2014

Keterangan: CA: Cagar Alam, HL: Hutan Lindung, HPK: Hutan Produksi Konversi 
sedangkan tanah terbuka seluruhnya terletak pada kawasan hutan produksi konversi. Berdasarkan SK.Departemen Kehutanan Nomor 891/Kpts-II/1999 tanggal 14 Oktober 1999 ditetapkan bahwa wilayah Distrik Oransbari terbagi dalam 3 fungsi kawasan hutan yaitu kawasan cagar alam, hutan lindung dan hutan produksi konversi (Dephut 1999). Sebelas penggunaan lahan di Distrik Oransbari terbagi dalam tiga fungsi kawasan hutan yaitu CA, HL dan HPK. Persen penggunaan lahan dalam fungsi kawasan hutan dapat dilihat pada tabel 2.

Penggunaan lahan di CA untuk hutan lahan kering primer memiliki persen terbesar yaitu $\pm 76,52 \%$ jika dibanding dengan fungsi kawasan hutan lainnya. Hasil pengamatan lapangan berdasarkan penutupan lahan pada areal hutan lahan kering primer ditemukan jenis-jenis tanaman antara lain Merbau (Intsia bijuga), Matoa (Pometia sp.), Palem (Areca sp.), Sagu (Metroxylon sp.), Bambu (Bambosa sp.), Beringin (Ficus sp.). Beberapa jenis tumbuhan berkayu yang memiliki nilai ekonomis tinggi sering digunakan oleh masyarakat untuk memenuhi kebutuhan bahan baku konstruksi rumah maupun kebutuhan lainnya. Sebagian besar daerah hutan yang mengalami perubahan menjadi bentuk penggunaan lain disebabkan letak hutan lahan kering primer yang berada dekat dengan jalan. Sedangkan pada bagian hutan lahan kering primer yang mengalami perubahan menjadi hutan disebabkan program reboisasi atau penanaman kembali bagian hutan yang telah mengalami kerusakan sebagian besar terletak di Warkwandi, Margorukun dan Watariri.

Faktor penyebab adanya kerusakan hutan di daerah penelitian termasuk di kawasan CA adalah aktifitas manusia. Tingginya aktifitas manusia dapat menyebabkan kerusakan hutan seperti penebangan yang tidak diiringi dengan penanaman kembali. Selain itu kerusakan yang terjadi akan meningkat jika didukung dengan kurangnya kesadaran masyarakat setempat mengenai manfaat dan fungsi hutan. Akibat kurangnya kesadaran dari masyarakat setempat akan menambah luasnya lahan kering sekunder, savana maupun semak belukar didaerah penelitian.

\section{Laju Perubahan Luas Penggunaan Lahan Pada Tahun 2006 Hingga Tahun 2014}

Perubahan penutupan lahan di suatu wilayah dapat ditelusuri dari teori land use. Teori ini menjelaskan bahwa kualitas lahan yang tinggi secara alamiah akan menjadi titik awal pertumbuhan aktivitas manusia (Waluyaningsih 2008). Laju perubahan penggunaan lahan di Distrik Oransbari dari tahun 2006 hingga 2014 disajikan pada tabel 3 .

Nilai negatif pada tabel 3 . menunjukkan bahwa terjadi penurunan luas penggunaan lahan sedangkan nilai positif menunjukkan pertambahan luas penggunaan lahan. Tabel 2 menunjukkan bahwa penggunaan lahan yang mengalami penurunan luasan paling tinggi adalah penggunaan lahan hutan lahan kering sekunder yang memiliki luas perubahan sebesar $1.719,00$ ha dengan rata-rata laju perubahan 156,27 ha/tahun disusul pertanian lahan kering yang memiliki luas perubahan sebesar 231,81 ha dengan rata-rata laju perubahan 21,67 ha/tahun sedangkan penambahan luas penggunaan lahan dengan rata-rata laju 
perubahan penggunaan lahan tertinggi adalah hutan lahan kering primer yang memiliki luas perubahan sebesar 531,01 ha dengan rata-rata laju 48,27 ha/tahun setelah itu disusul permukiman yang memiliki luas perubahan sebesar 235,02 ha dengan rata-rata laju perubahan 21,37 ha/tahun. Berdasarkan peta penutupan lahan tahun 2006 dan 2014 diduga penurunan luas kawasan hutan lahan kering primer dan hutan lahan kering sekunder disebabkan oleh konversi penggunaan lahan menjadi semak/belukar, savana, penggunaan lahan pertanian lahan kering dan permukiman.

Tabel 3. Rata-rata laju perubahan penggunaan lahan tahun 2006-2014

\begin{tabular}{lcc}
\hline Bentuk Penggunaan Lahan & $\begin{array}{c}\text { Perubahan Penggunaan } \\
\text { Lahan (Ha) }\end{array}$ & $\begin{array}{c}\text { Rata-Rata Laju Perubahan } \\
\text { Per Tahun (Ha) }\end{array}$ \\
\hline Hutan Lahan Kering Primer & 531.01 & 48.27 \\
Semak / Belukar & -11.62 & -1.06 \\
Hutan Lahan Kering Sekund & -1719.00 & -156.27 \\
Pertanian Lahan Kering & -231.81 & -21.67 \\
Awan & 1120.62 & 101.87 \\
Savana & -59.59 & -5.42 \\
Badan Air & 2.96 & 0.27 \\
Perkebunan & 30.64 & 2.79 \\
Pemukiman & 235.02 & 21.37 \\
Tanah Terbuka & 9.84 & 0.89 \\
Sawah & 141.22 & 12.84 \\
Hutan Mangrove & -49.35 & -4.49 \\
\hline
\end{tabular}

Sumber: Analisis Data 2014

Sandy (1995) dalam Utoyo (2012) menyatakan bahwa lahan yang subur lebih banyak digunakan untuk pertanian dan biasanya berpenduduk padat konversi lahan ke penggunaan lahan pertanian lahan kering umumnya dipilih areal yang subur. Berdasarkan anlisis peta penutupan lahan peningkatan perubahan lahan menjadi permukiman umumnya terjadi di sekitar areal pertanian.

Perubahan luas penggunaan lahan selain di kaji dari faktor fisik terdapat faktor yang mendominasi perubahan di daerah daratan yaitu faktor manusia. Apabila kita melihat dari faktor manusia, perubahan yang paling utama adalah pengaruh dari bertambahnya jumlah penduduk, yang berdampak pada penggunaan lahan permukiman (Lainatussifa 2005). Semakin tambah jumlah penduduk, pasti akan bertambah pula tempat mukim. Pertambahan jumlah penduduk akan membawa perubahan pada lahan yang dimanfaatkan pada mata pencaharian, diantaranya sawah dan pertanian lahan kering (pekarangan dan tegalan).

\section{DAFTAR PUSTAKA}

As-syakur AR. 2011. Perubahan penggunaan lahan di Provinsi Bali. Jurnal Ecotrophic, Vol 6 (1): 1-7.

Badan Standarisasi Nasional (BSN). 2010. Klasifikasi penutup lahan. Penerbit BSN. Jakarta.

Departemen Kehutanan Republik Indonesia. 1999. SK Nomor 891/KptsII/1999 tentang pembagian kawasan hutan di Kabupaten Manokwari. 
Feriyawan CY dan P Danoedoro. 2012. Kajian kemampuan jaringan syaraf tiruan algoritma backpropagation untuk klasifikasi penggunaan lahan menggunakan Citra Alos AVNIR-2. Tesis Fakultas Geografi UGM. Yogyakarta. (Tidak diterbitkan).

Lainatusifa D. 2005. Kajian perubahan penggunaan lahan dipesisir dan pantai Kabupaten Demak melalui penginderaan jauh dan sistem informasi geografi 1972-2005. Skripsi. Fakultas Geografi UGM. (Tidak diterbitkan).

Purwadhi dan Sanjoto. 2008. Pengantar interpretasi citra penginderaan jauh. Pusat Data Penginderaan Jauh Lembaga Penerbangan Dan Antariksa Nasional dan Jurusan Geografi Universitas Negeri Semarang.

Sinaga R. 2004. Pemanfaatan penginderaan jauh dan sistem informasi geografi dalam mengkaji perubahan penggunaan lahan di Kecamatan Umbulharjo tahun 19932004. Tugas akhir Fakultas Geografi Universitas Gadjah Mada. Yogyakarta. (Tidak diterbitkan).

Sutanto. 1987. Penginderaan jauh. Volume 2. Gadjah Mada University Press, Yogyakarta.

Talane VM. 2014. Pendugaan potensi hutan mangrove di Distrik Oransbari Kabupaten Manokwari Selatan. Skripsi Fakultas Kehutanan Universitas
Negeri Papua. Manokwari. (Tidak diterbitkan).

Utoyo BS. 2012. Dinamika penggunaan lahan di wilayah perkotaan (Studi di Kota Bandar Lampung). Seminar hasil-hasil penelitian dan pengabdian kepada masyarakat- Dies Natalis FISIP Unila. Lampung.

Wahyunto MZ, Abidin A, Priyono dan Sunaryo. 2001. Studi perubahan penggunaan lahan di Sub DAS Citarik Jawa Barat dan DAS Kaligarang, Jawa Tengah. Prosiding Seminar Nasional Multifungsi Lahan Sawah. Balai Penelitian Tanah. Bogor.

Waluyaningsih SR. 2008. Studi analisis kualitas tanah pada beberapa penggunaan lahan dan hubungannya dengan tingkat erosidi sub DAS Keduang Kecamatan Jatisrono Wonogiri. Tesis: Program Studi Ilmu Lingkungan, Program Pascasarjana Universitas Sebelas Maret Surakarta. https://eprints.uns.ac.id/6409/1/752413 07200906001.pdf.

Wibowo TS. dan R Suharyadi. 2012. Aplikasi object-based image analysis (OBIA) untuk deteksi perubahan penggunaan lahan menggunakan Citra Alos AVNIR-2. Tesis Fakultas Geografi UGM. Yogyakarta. (Tidak diterbitkan).

Zain AS. 1998. Kamus kehutanan. Rineka Cipta. Jakarta. 
Lampiran 1. Peta lokasi penelitian Kajian Perubahan Penggunaan Lahan Menggunakan Sistem Informasi Geografis (SIG) dan Penginderaan Jauh di Distrik Oransbari, Manokwari Selatan.

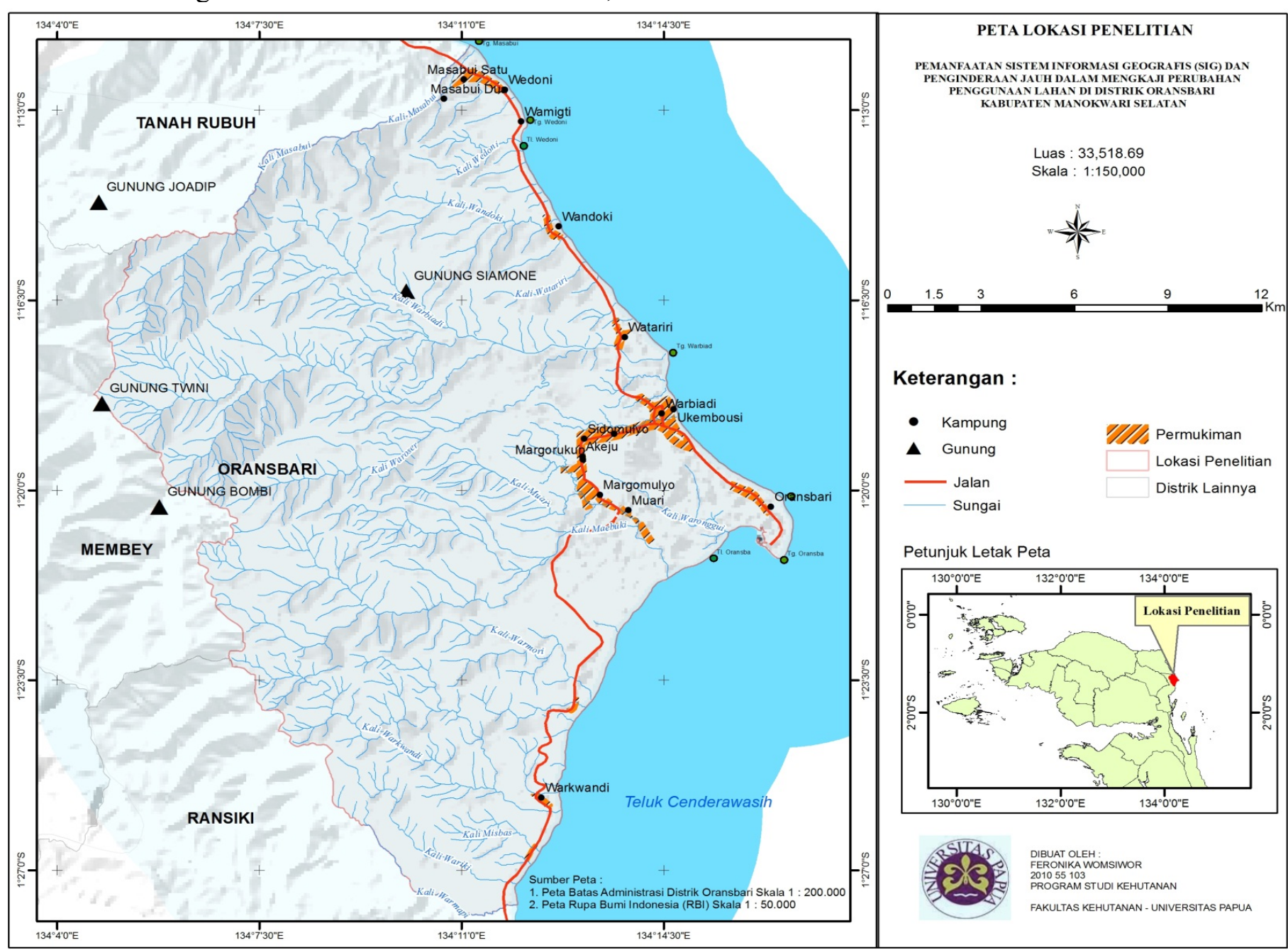




\section{Lampiran 2. Peta fungsi kawasan}

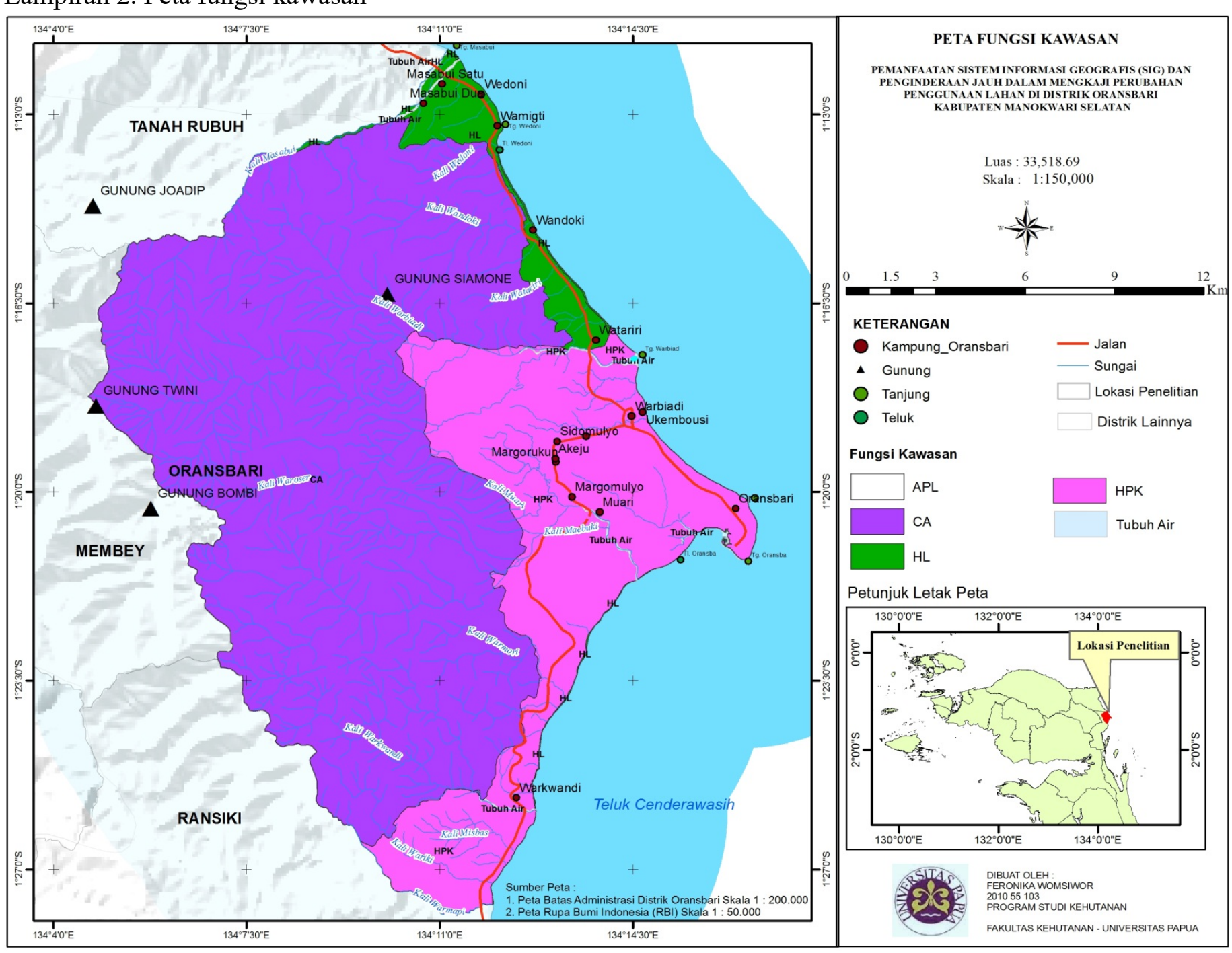

73

(a) Asosiasi Peneliti Biodiversitas Papuasia - Fakultas Kehutanan UNIPA 


\section{Lampiran 3. Peta penggunaan lahan tahun 2006}

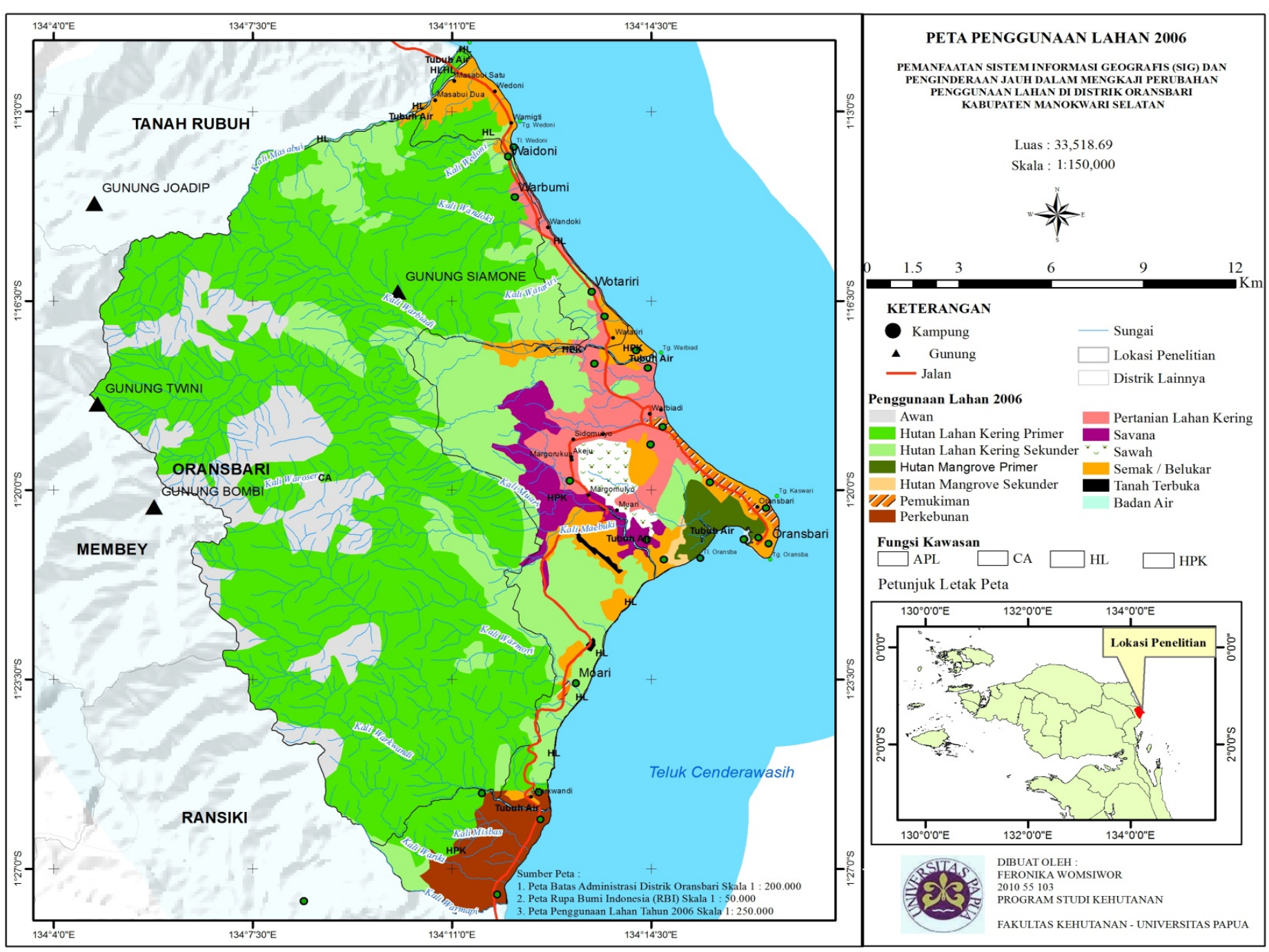


Lampiran 4. Peta penggunaan lahan tahun 2009

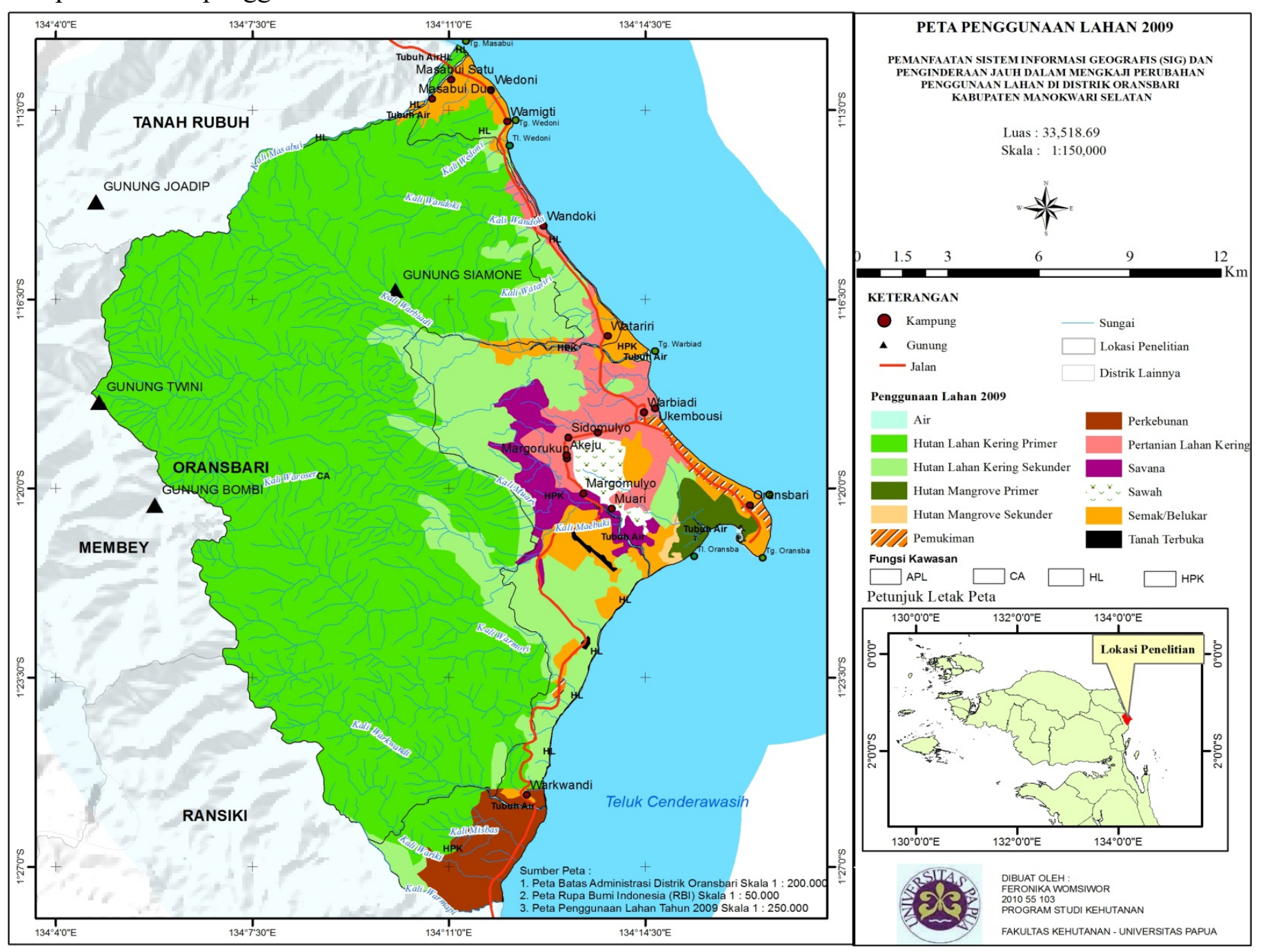

75

(a) Asosiasi Peneliti Biodiversitas Papuasia - Fakultas Kehutanan UNIPA 


\section{Lampiran 5. Peta penggunaan lahan tahun 2012}

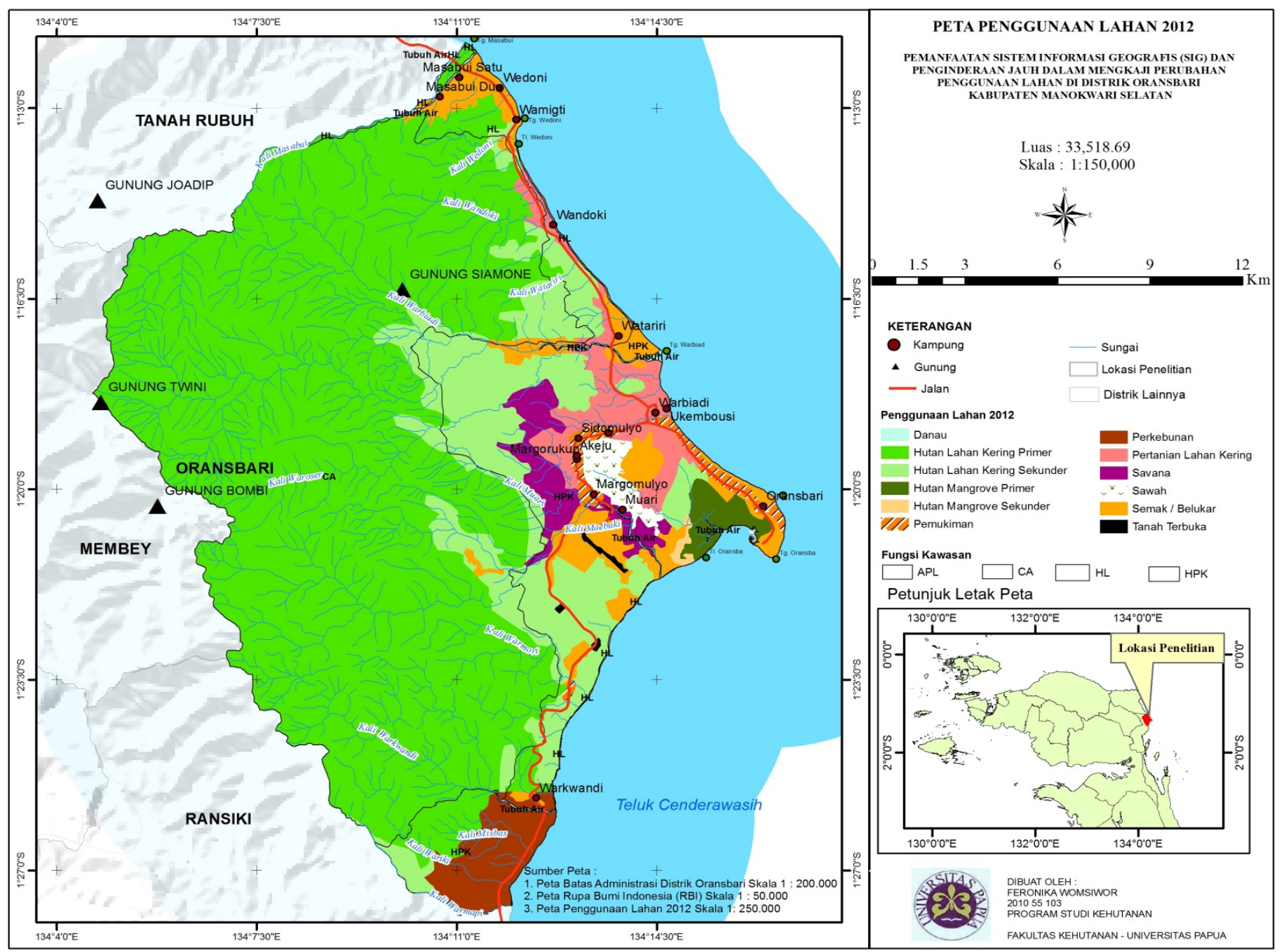




\section{Lampiran 6. Peta penggunaan lahan tahun 2014}

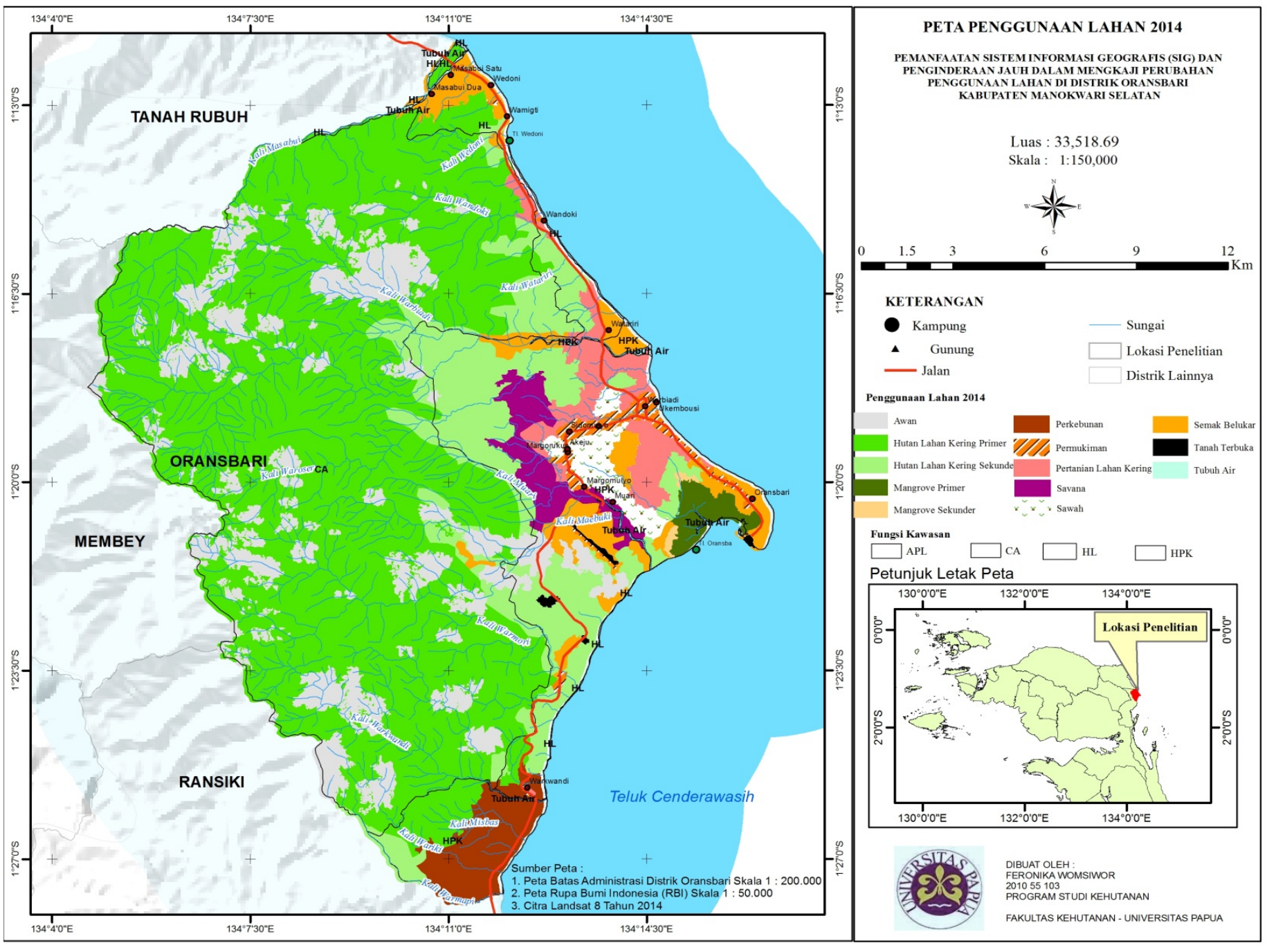

77

@ Asosiasi Peneliti Biodiversitas Papuasia-Fakultas Kehutanan UNIPA 
Lampiran 7. Peta citra landsat tahun 2014

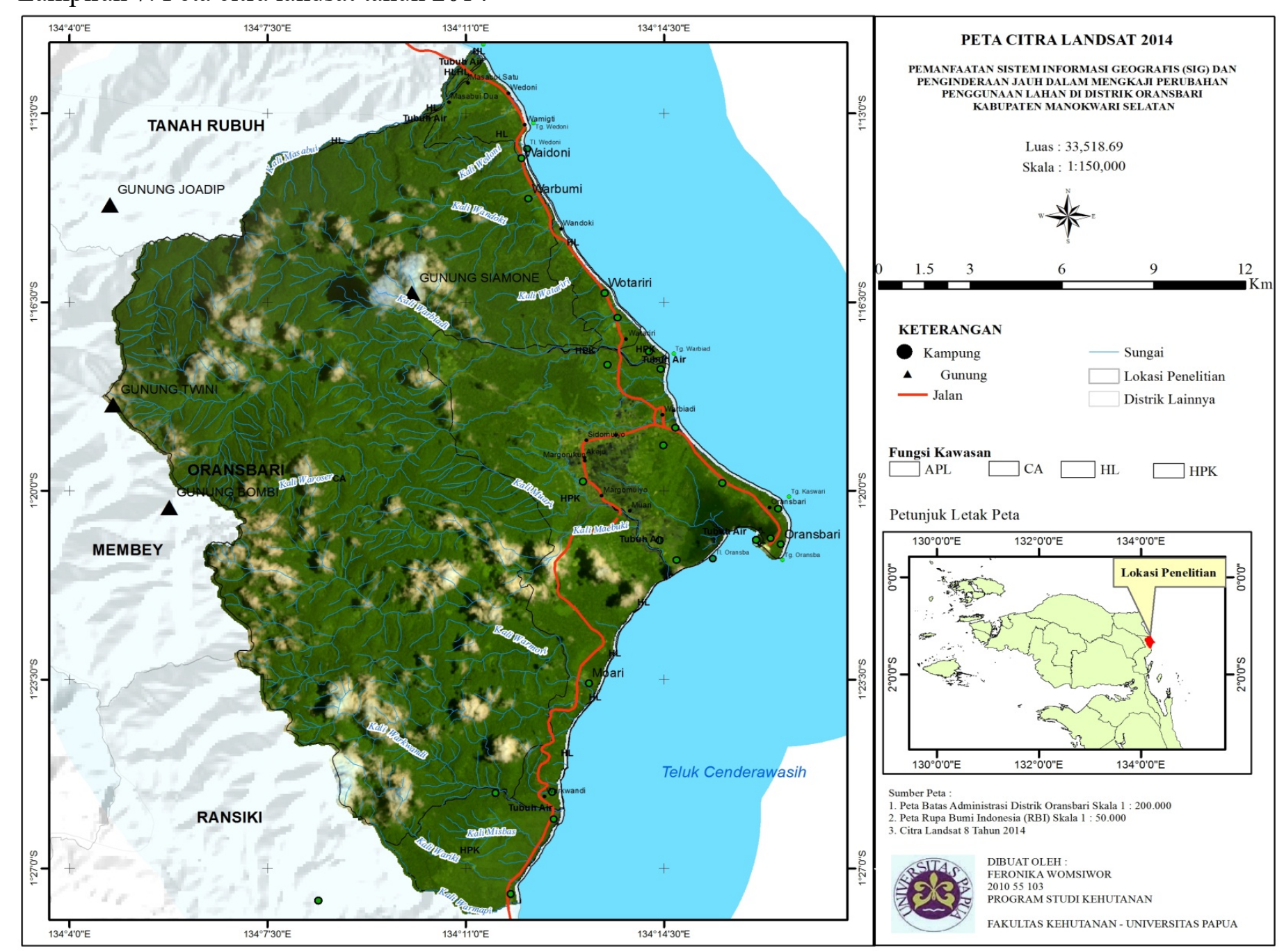

